On the Doorstep of Europe 
THE ETHNOGRAPHY OF POLITICAL VIOLENCE

Tobias Kelly, Series Editor

A complete list of books in the series is available from the publisher. 


\title{
ON THE DOORSTEP OF EUROPE
}

\author{
ASYLUM AND CITIZENSHIP IN GREECE
}

HEATH CABOT

\section{$\overline{\text { PENN }}$}

UNIVERSITY OF PENNSYLVANIA PRESS

PHILADELPHIA 
Copyright @ 2014 University of Pennsylvania Press

All rights reserved. Except for brief quotations used for purposes of review or scholarly citation, none of this book may be reproduced in any form by any means without written permission from the publisher.

Published by

University of Pennsylvania Press

Philadelphia, Pennsylvania 19104-4112

www.upenn.edu/pennpress

Printed in the United States of America on acid-free paper

1098766543221

Library of Congress Cataloging-in-Publication Data

Cabot, Heath.

On the doorstep of Europe : asylum and citizenship in Greece / Heath Cabot. - 1st ed.

p. $\quad \mathrm{cm}$. - (The ethnography of political violence)

Includes bibliographical references and index.

ISBN 978-0-8122-4615-5 (hardcover : alk. paper)

1. Political refugees-Legal status, laws, etc.-Greece. 2. Emigration and immigration law-Greece. 3. Asylum, Right of-Greece. 4. Legal assistance to refugees-Greece. 5. Social work with immigrants-Greece. 6. Citizenship-Greece. I. Title. II. Series: Ethnography of political violence.

JV8118.C33 2014

$325.495-\mathrm{dc} 23$ 
"Peace be forever on the houses and citizens of Athens." -Aeschylos, The Eumenides 
